\title{
ASSESSMENT OF CORPORATE SOCIAL RESPONSIBILITY AND ITS IMPACTS ON CORPORATE REPUTATION OF COMPANIES IN SELECTED BALKAN COUNTRIES FORMER YUGOSLAVIA STATES
}

\author{
Jintao LU®1,2*, Licheng REN ${ }^{1,2}$, Chong ZHANG $^{1}$, Jiayuan QIAO $^{1}$, \\ Maria KOVACOVA ${ }^{3}$, Justas STREIMIKIS ${ }^{4}$ \\ ${ }^{1}$ School of Economics and Management, Taiyuan University of Science and Technology, \\ 030024 Taiyuan, P.R. China \\ ${ }^{2}$ Research Center for Corporate Social Responsibility, Taiyuan University of Science and Technology, \\ 030024 Taiyuan, P.R. China \\ ${ }^{3}$ Department of Economics, Faculty of Operation and Economics of Transport and Communications, \\ University of Zilina, Univerzitna 1, 01026 Zilina, Slovak Republic \\ ${ }^{4}$ Division of Farms and Enterprises Economics, Lithuanian Institute of Agrarian Economics, \\ V. Kudirkos g. 18, 01113 Vilnius, Lithuania
}

Received 23 September 2019; accepted 31 December 2019

\begin{abstract}
The empirical study was conducted in the three selected Balkan Countries from former Yugoslavia: Slovenia, Croatia and Montenegro through totally 270 experts' surveys, 90 questionnaires were distributed to entrepreneurs (30), policy makers (30) and experts from academia (30) in each country in order to assess the CSR level in the country and the effect the main drivers having on CSR level, then followed by the assessment of CSR impacts on Corporate Reputation (CR). The model of multivariate regression was developed for assessment of the impact of the four independent variables (Institutional Environment, Executive Characteristics, Customers' Expectations and Political Factors) on dependent variable-CSR. The study also analysed the impact of CSR (dependent variable) on CR. The obtained results show that countries with the higher level of CSR, have achieved the greater level of CR. The degree of the impact of the main drivers on CSR in selected Balkan countries is linked to EU accession level. The political factor has the highest impact on CSR level in all investigated countries, institutional environment is the next.
\end{abstract}

Keywords: corporate social responsibility, corporate reputation, institutional environment, drivers, Balkan countries.

JEL Classification: Q01, Q35, Q51.

\footnotetext{
*Corresponding author. E-mail: lut2002@163.com
} 


\section{Introduction}

Countries in the world are currently facing the important global problems related to climate change and other risks. Political, economic, and environmental issues are increasingly becoming the responsibility of international business leaders as much as governments. Corporate Social Responsibility (CSR) plays an important role in dealing with those global challenges.

Such as Chinese government is conducting the "The Belt and Road" project (Chen et al., 2019) which includes 66 countries, therefore the samples from the countries along the Belt and Road are useful to investigate their current situations and advanced experiences, and to propose several key policy implications for "One Belt, One Road" project in the end to reach its final "all-win" purpose for all involved countries. The Balkan is the last part of Europe, bordering the Middle East, which has important strategic value. Some Balkan countries are European Union (EU) member states and some of them are just in the preparation phase to join EU. Therefore, it is interesting to investigate the impact of joining EU on CSR development in former Yugoslavia region. Slovenia first joined EU in 2004, the next Balkan country entering EU was Croatia which joined EU as its 28th member state on 1 July 2013. Montenegro is not EU member state and this country is just negotiating access to EU.

Balkan countries have experienced a lot of diverse challenges in their transition. According to The World Economic Forum's (WEF) Global Competitiveness Index covering 141 economies of the world, Balkan countries from former Yugoslavia remain the quite low status. What is visible in GCI report for 2019, Slovenia reached $35^{\text {th }}$ position in 2019 comparing with $57^{\text {th }}$ in 2011 . Croatia moved from $76^{\text {th }}$ position in 2011 to $63^{\text {th }}$ in 2019 . Montenegro - from $60^{\text {th }}$ in 2011 to $73^{\text {th }}$ in 2019 (Draskovic \& Stjepcevic, 2012; World Economic Forum, 2019). Balkan countries have inherited the common problems from their socialist past in former Yugoslavia: unbalanced and non-transparent institutional framework, low knowledge level and low experience in advanced business practices including management in the markets with high ownership concentration, underdeveloped capital markets in public sectors, the agency problem between the majority and minority shares owners in companies, etc. (Dialogue of Civilizations Research Institute, 2018). Also, it should be stated that observed counties had different path after the Yugoslavian separation. Montenegro got independency in 2006, Croatia and Slovenia in 1991. War in Croatia and post war period (peaceful integration) lasted until 1998.

There are many recent studies analyzing the main drivers and determinants of CSR and its impacts (Bakan, 2004; Hult, 2011; Drummet, 2006; Christensen et al., 2013; Öberseder et al., 2013, 2014; Mapelli et al., 2016; Ali et al., 2017; Dyduch \& Krasodomska, 2017; Hafenbradl \& Waeger, 2016). The main drivers and determinants of adoption of sustainable business practices such as CSR, identified by the authors are based mainly on institutional factors (Aoki, 2001; Postma \& Hermes, 2003; Fiss, 2008; Fox et al., 2002; Roe, 2004; Draskovic \& Stjepcevic, 2012; Draskovic \& Lojpur, 2013) and less on the utilities determination responded to society and customer's needs (Abbas et al., 2018; Öberserder et al., 2013, 2014; Vlachos et al., 2009; Yuen et al., 2016; Stanisavljević, 2017; Li et al., 2019) or executive characteristics such as leadership (Hafenbradl \& Waeger, 2016; Barker \& Mueller, 2002; Christensen et al., 2013; Kang et al., 2016; Maak et al., 2016; Petrenko et al., 2016; Lu et al., 2019c) or other factors. 
In Balkan region several important case studies on CSR were conducted in specific sectors of economy for Bosnia and Hercegovina (Cavalic, 2017; Prutina \& Sehic, 2016; Prutina, 2016); Bulgaria (Matev \& Asenova, 2012; Koleva et al., 2010); Romania (Iamandi \& Constantin, 2012; Ioannouu \& Serafeim, 2012). However, the situation in Balkan countries requires special attention taking into account the aforementioned situation and challenges of transition. There are no empirical studies dealing with comparative assessment of CSR and CR in selected Balkan countries, therefore this study purposes to fill this gap and aims to assess the CSR levels of the countries and explore the effect of CSR initiatives of enterprises on their CR in three selected Balkan countries: Slovenia (SLO), Croatia (CRO) and Montenegro (MON) which have inherited from former Yugoslavia similar problems while are in the different position towards the access to EU because of different transformations undergone after the Yugoslavian separation.

The model of multiple hierarchical regression was applied in order to determine the impact of the main drivers of CSR in selected countries. This main strength of this approach is simple and clear presentation of the main drivers and their impact on CSR level in three Balkan countries based on expert surveys conducted in these countries. However, this approach has some shortages linked to the limited number of questions provided in survey for defining the relationships of independent variables with dependent variable. The limitations of this study can be avoided by conducting similar research and applying more robust techniques as Structural Equation Modelling etc.

The rest of this study is structured as follows. The following Section 1 is devoted to a review of literature in order to define the main drivers of CSR; In Section 2, the methodology for assessment of CSR level and its impacts on CR is developed; In Section 3 the results of empirical studies are discussed; Finally, the conclusion and some directions for future research are given in last section.

\section{Literature review}

There are several key topics in current research on determinants of implementation of CSR; communication and stakeholder commitment, quantification of CSR levels and valuation of various CSR outcomes (Lu et al., 2019a). CSR concept covers a wide range of issues linked to the role and functions of business in present society (Jonker, 2005). According to the definition of Van Marrewijk (2003) the CSR “...refers to company activities - voluntary by definition - demonstrating the inclusion of social and environmental concerns in business operations and in interactions with stakeholders". The following key principles connect all available concepts and definitions of CSR proposed in well-known studies (Carrol, 1979, 1999, 2000, 2016; Wood, 1991; Moir, 2001; Nazari et al., 2012; Zink, 2007): involvement in community life, accountability, sustainability, clearness, honest and ethical behavior etc. The common characteristics of CSR identified by scholars can be divided into the following categories: CSR practices are common and relevant to all types of businesses; CSR initiatives are voluntary; they involve interactions with the stakeholders; imposing responsibility for society to provide input to the quality of life; socially responsible companies grasp "triple results" approach covering the contributions to economy, society and environment. 
Various CSR issues have been investigated in the economic, management, organizational, institutional studies from various perspectives in terms of conceptual frameworks, drivers, impacts, benefits and policies to promote CSR (Carroll, 1979, 1999, 2000, 2016; Carol \& Bucholtz, 2008; Moir, 2001; Margolis \& Walsh, 2003; Van Marrewijk, 2003; Aguilera \& Jackson, 2003; Wood, 1991; Aoki, 2001; Poksinska et al., 2003; Crane et al., 2009; Garriga \& Melé, 2004; Romani et al., 2016; Yoo \& Lee, 2018; Lu et al., 2019a). Currently, organizations are experiencing various forces to deal with societal concerns (Lewis, 2003; Margolis \& Walsh, 2003; Matten et al., 2003; Pedersen, 2006). Consequently, enterprises have been triggered to the significance of contributing to society, and started to implement CSR practices. The scholars were broadly analyzing various institutional factors and structures having impact on CSR movement and its development especially in advanced economies with high quality institutions and well developed social capital (Aoki, 2001; Postma \& Hermes, 2003; Fiss, 2008; Fox et al., 2002; Roe, 2004; Draskovic \& Stjepcevic, 2012; Draskovic \& Lojpur, 2013).

Scholars agree that the efficient management of the enterprises involves the establishment of long lasting coherent relationships and productive communication with all the stakeholders involving in business processes and supply chains (Zingales, 1997; Higgins, 2002; Apreda, 2006; Pedersen \& Neergaard, 2006; Kang et al., 2016). Some authors also stressed the current increasing pressure of state agencies and Non-Governmental Organizations (NGOs) on business entities in terms of their social responsibility due to global environmental problems and other risks (Crane et al., 2009; Kolk, 2016). However, most authors agree that the CSR is not achievable without establishment of a firm institutional framework. The most important preconditions for its development are: corporate citizenship, social partnership and societal investments (Draskovic \& Stjepcevic, 2012). The Corporate Governance (CG) is the part of CSR which includes several important participants: shareholders or individual and institutional owners, employees, internal and external managers and corporate constituents. Their related interactions are multifaceted and are enforced by the institutions through formal or informal rules which are necessary to follow. Consequently, the proper institutional environment requires operational corporate governance. As it well known that the effective institutional structure is the main prerequisite of sustainable economic development, it is reasonable to apply the same cause-and-effect relationship to CG and CSR (Aoki, 2001; Postma \& Hermes, 2003; Fiss, 2008).

CG is the set of policies, laws, processes, and institutions having impact on modes of directing, administering and controlling of enterprises. Study by Miras-Rodriguez del Mar et al. (2019) investigated CG mechanisms driving CSR in emerging economies. There are many informal institutions affecting the corporate governance, companies' specific norms and values, ethical codes, culture of organization, as well as public norms and values of the society, self-regulation processes and structure in industries (Bice, 2015; Martin, 2015; Everard et al., 2016). The brand, image, identity and corporate reputation of a company and its interactions with competitors, suppliers and consumers also play a major role (Lu et al., 2019a). The corporate governance institutions provide formal or informal contracts among diverse stakeholders (Fox et al., 2002; Jonker, 2005; Aguilera et al., 2007; Pesmatzoglou et al., 2014).

The political connections of companies are also found as important determinants of institutional environment which have impact on CSR initiatives especially among transition 
countries (Maitland et al., 2009; Maak et al., 2016; Huang \& Zhao, 2016). There are many ways to define political connections. Political connections can be focused on direct political linkages, i.e., relations between present or former top managers, employees, or investors and politicians, or on indirect political connections such as campaign contributions and lobbying activities. North (1990) developed an institutional matrix with the aim to rationalize the legal, cultural and normative constituents of the companies' environment. The importance of the institutional matrix is implied in its impacts on the strategic choices of companies. Draskovic and Lojpur (2013) pointed that in the case of underdeveloped institutional framework, the informal instructions and the informal institutions based on the personal relationships become more imperative. The formal and informal institutions work together by supplementing or replacing each other. In conclusion, Babić (2010) argued that the discussion on CG and CSR always ends up with the problem of anxiety between individual freedom and institutional power.

In Figure 1 the main institutional and other factors having impact on CG and CSR are given.

In recent literatures CSR has also been regarded as a successful tool for companies to improve their reputation and create strong brand image to influence the customer's loyalty. Many authors highlighted that appealing to CSR activities provides for enhancing CR in various ways (Li et al., 2018; Lu et al., 2019b; Mapelli et al., 2016; Kudlak et al., 2018; Lewis, 2003; Dean, 2002; Dixit, 2009; Dummet, 2006; Danubianu \& Teodorescu, 2017). Progressively, by engaging in CSR activities firms are trying to differentiate themselves from other competitors, create an expressive ties with their clients, stimulate employee satisfaction and loyalty to the company, build a basis for a greater customer tolerance to the growth of prices, create advantageous publicity, increase understanding of skeptical and negatively-oriented public officials and enhance CR and strengthen brand loyalty (Lu et al., 2019b). Therefore, scholars have identified customer's expectations and loyalty as important drivers for implementation of CRS (Abbas et al., 2018; Öberserder et al., 2013, 2014; Vlachos et al., 2009; Yuen et al., 2016; Stanisavljević, 2017; Li et al., 2019). The customer's expectations are also influenced by institutional environment. However, customer's loyalty is mainly attributed to corporate brands and reputations of companies. There is a dual relationship between CR and CSR as

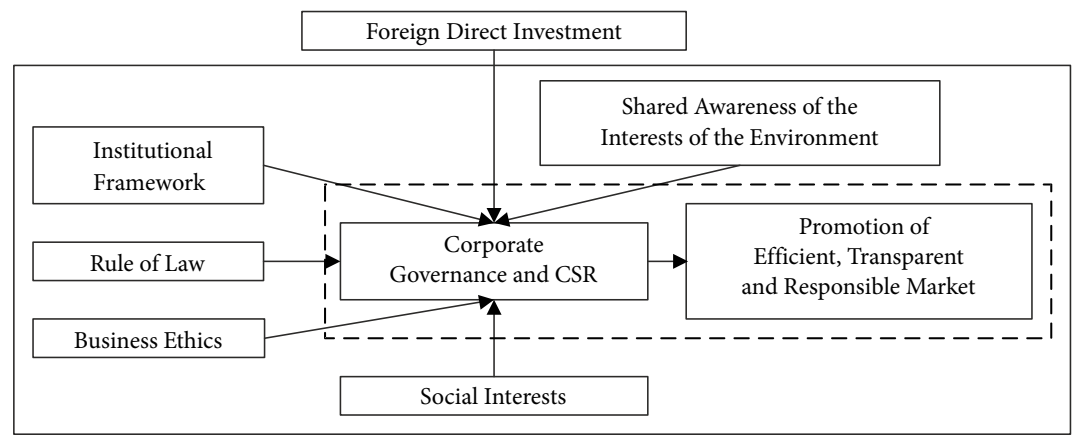

Figure 1. Institutional and other factors having impact on CG and CSR (source: created by authors based on Jonker, 2005; Draskovic \& Stjepcevic, 2012) 
CSR can generate various advantages for the firm, nevertheless, in the case of bad reputation, the influence of CSR can be unfavourable for the company due to corporate hypocrisy issues (Yoon et al., 2006). This mutual underpinning connection is very important for firms during preparation of their differentiation strategies and planning strategic investments in intangible assets such as CSR. Besides that, the responsiveness of stakeholders plays very important roles when analysing the influence of CSR on corporate reputation. Hillenbrand and Money (2007) indicated that there are two alternate standpoints: CSR is a determinant of the CR, and CSR is a main component of CR. Therefore, it is possible to state that CSR corresponds to CR in terms of corporate behaviours and stakeholder insights. Hence, based on study by Hillenbrand and Money (2007), the CSR and CR can be treated "as two sides of the same coin".

The micro-foundations of CSR are linked to the analysis of characteristics of CEOs and leadership styles as main determinants of CSR in enterprises (Barker \& Muller, 2002; Chin et al., 2013). The current studies on executive characteristics and their belief in the business case for CSR (Hafenbradl \& Waeger, 2017; Maak et al., 2016) are formed on two grounds. First, executives need factual evidence to believe that business case indeed exists. The second statement is that those executives who do believe in the business case are keener to invest in CSR-related activities. The recent study by Hafenbradl \& Waeger (2017) provided that if managers trust in a fair market ideology in the business case for CSR, they are not more persuaded to engage in CSR than managers who did not hold such an ideology due to a weaker moral reaction linked to ethical problems. Other studies investigated ethical leadership and other CEO characteristics including political ideologies which have impacts on willingness to engage in CSR practices (Christensen et al., 2013; Kang et al., 2016; Maak et al., 2016; Petrenko et al., 2016; Lu et al., 2019c). Therefore, the executive characteristics have been found as important factors driving CSR movement.

Analysis of various theoretical models and empirical studies on CSR and CG shows the importance of institutional environment including political relations for CSR and CG realization and progress. The institutional environment is comprised of regulations, customs and norms prevailing in societies, professions and organizations, which impose upon and shape organizational behavior.

Formal and informal institutions provide the main elements for the governance structure at diverse levels of firm's interaction within an economy. One significant level of interaction is the corporate level. According to views from many scholars, the appropriate institutional frameworks are necessary for creation and maintenance of the resilient CSR framework. Therefore, based on literature analysis conducted above, the institutional factors were found as an obligatory prerequisite for operational CG and effective CSR initiatives. As customer's expectations and executive characteristics play important roles in driving CSR practices, these drivers were also included in theoretical model presented in Figure 2.

The theoretical model will be practically tested by empirical studies in several selected Balkan countries which have the same inherited institutional environment from former Yugoslavia though they have achieved different progress towards the access to EU and experienced very diverse transformations after regain of independence (Dialogue of Civilizations Research Institute, 2018). 


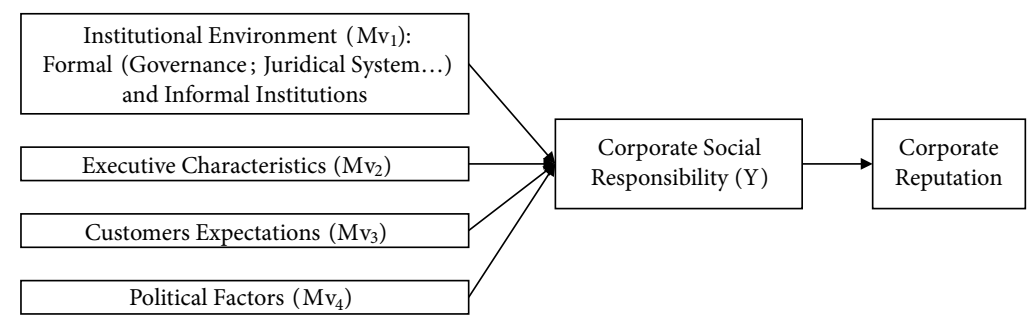

Figure 2. The theoretical model

The main hypotheses were presented as follows:

$\mathrm{H1}$ : The institutional environment and political relations are the main drivers of CSR level as well as CR of enterprises in selected Balkan countries;

$\mathrm{H} 2$ : The degree of the impact of the main drivers on CSR in selected Balkan countries is linked to EU accession level.

The methodology for a quantitative assessment of CSR level in the countries and the impact of the main drivers presented in Figure 2 is presented in the next section.

\section{Methodology}

270 experts' surveys were conducted in three countries Montenegro (MON), Croatia (CRO), and Slovenia (SLO) from $21^{\text {st }}$ July 2019 to $1^{\text {st }}$ September 2019, respondents include experts from owners of companies in the private sector (30 entrepreneurs), State administration officials with an academic title (30 policy makers) and university professors and assistants (30 experts from academia). They were surveyed in personal in each country in order to assess the CSR level in the country and the effect the main drivers have on CSR level, then followed by the assessment of CSR impacts on CR. A Snowball sampling approach was applied. A small pool of initial informants was used to nominate, through their social networks, other participants who meet the eligibility criteria and could potentially contribute to a specific study. The respondents were asked to assess using the scores, based on their practise and understanding, the dependent variable in the model, described as the achieved level of CSR. The respondents were asked to assess situation only in their home country. During experts survey they were also requested to score the values of four independent variables in the model, which related to: institutional environment, executive characteristics, customers' expectations, political factors, and the level of realized CSR influence on the level of CR.

In three countries experts applied scores based on a Likert-type scale $(1.0,1.5,2.0,2.5$, $3.0,3.5,4.0,4.5,5.0$ ), where 1.0 indicates the lowermost influence, and 5.0 indicates the uppermost effect. For the needs of the survey, the respondents have been selected from three important areas linked to CSR: owners of private sector firms (private sector entrepreneurs), state administration officials with an academic title, and the university professors and assistants. Following regression analysis has included both separate and integral data for all three considered groups. 


\subsection{Descriptive statistics}

Descriptive statistical analysis of the obtained data indicated that the assumptions of normality and linearity of multi-correlation were met. This justifies the use of regression analysis of the first-order model. All extreme values and atypical points were verified, and they also met the prerequisites for the application of the multiple-linear regression model, for determination of the correlation among the dependent variable and the four independent ones. It is essential to state that the correlation coefficient $(r)$ and the coefficient of determination $\left(r^{2}\right)$ are quite large (see Table 1). This also justifies the use of a multiple linear regression model.

Table 1. Coefficient correlation $(r)$ and Coefficient of determination $\left(r^{2}\right)$

\begin{tabular}{|c|c|c|c|}
\hline & MON & CRO & SLO \\
\hline$r$ & 0.846 & 0.933 & 0.952 \\
\hline$r^{2}$ & 0.715 & 0.871 & 0.906 \\
\hline
\end{tabular}

\subsection{Model of multiple hierarchical regression analysis}

The dependent variable was described as the achieved level of CSR in the model. The experts were also requested to score the values of four independent variables, including institutional environment, the executive characteristics, customers' expectations; political factors, the level of realized CSR influenced the level of CR.

The aim is to determine the functional association of the dependent variable (the level of CSR achieved - $Y$, and independent variables in the model (respectively): institutional environment $\left(\mathrm{Mv}_{1}\right)$, the executive characteristics $\left(\mathrm{Mv}_{2}\right)$, customers' expectations $\left(\mathrm{Mv}_{3}\right)$, and political factors $\left(\mathrm{Mv}_{4}\right)$. The idea is to assess the anticipated mean value of the dependent variable $(\bar{Y})$, established on the basis of distinctive assessments of the experts. After evaluation of the dependent variable, and their dependence on the variables $\left(\mathrm{Mv}_{1-4}\right)$ the regression coefficients can be determined $\left(b_{0}, b_{1}, b_{2}, b_{3}, b_{4}\right)$, and the coefficients of formula can be calculated using Eq. (1):

$$
\bar{Y}=b_{0}+b_{1} \mathrm{Mv}_{1}+b_{2} \mathrm{Mv}_{2}+b_{3} \mathrm{Mv}_{3}+b_{4} \mathrm{Mv}_{4},
$$

where: $\bar{Y}$ - is the mean expected value of the dependent variable; $b_{0}$ - is Y-axis intercept, established based on the applied model; $b_{1}, b_{2}, b_{3}, b_{4}$ - are constants of the independent variables $\mathrm{Mv}_{1}, \mathrm{Mv}_{2}, \mathrm{Mv}_{3}, \mathrm{Mv}_{4}$, correspondingly, or the slopes of the matching lines. That implies that each independent variable value in defined interval, the value of the dependent variable can be assessed or it is possible to state that $\bar{Y}$ is "average" assessed value since it is the mean value of the probability dissemination of all possible $Y$ values for a given values of $\mathrm{Mv}_{1}, \mathrm{Mv}_{2}, \mathrm{Mv}_{3}, \mathrm{Mv}_{4}$.

In order to define the value of $\bar{Y}$ the least-squares method was employed (Bertsekas \& Nedic, 2003). However, the main aim is to fix the following coefficients: $b_{0}, b_{1}, b_{2}, b_{3}, b_{4}$ by minimizing the sum of squared errors (SSE) in Eq. (2):

$$
S S E=\sum_{k=1}^{n}\left(Y_{k}-\bar{Y}_{k}\right)^{2}=\sum_{k=1}^{n}\left(Y_{k}-\left(b_{0}+b_{1} X_{1 k}+b_{2} X_{2 k}+b_{3} X_{3 k}+b_{4} X_{4 k}\right)\right)^{2} \text {, }
$$


where: $Y_{k}$ - the genuine value given by $k$ experts $(k=\overline{1, n})$ for the dependent variable $Y$; $\bar{Y}_{k}$ - the assessed value of the dependent variable by the model based on the sample of $k$ experts $(k=\overline{1, n}) ; n-$ is the total number of experts in survey (90 in MON, 90 in CRO, and 90 in SLO).

By applying the least-squares technique, the minimization of the sum of vertical differences for each pair of points is obtained on horizontal line (Balakrishnan et al., 2012). Or, in other words, the best fits of the available distribution of points was obtained, by defining the optimal value of Y-axis intercept $\left(b_{0}\right)$, as well as coefficient $\left(b_{0}, b_{1}, b_{2}, b_{3}, b_{4}\right)$, in turn to obtain a more precise value of $\bar{Y}$ for the assessed values of $X_{i}, i=\overline{1,4}$ and $\mathrm{Y}$ (for $\forall k, k=\overline{1, n}$ ). Therefore, the optimal average value of the dependent variable is determined by $\bar{Y}_{k}$ on the basis of the values of independent variables $\left(\mathrm{Mv}_{1}, \mathrm{Mv}_{2}, \mathrm{Mv}_{3}, \mathrm{Mv}_{4}\right)$ and the dependent variable (Y), for $\forall k, k=\overline{1, n}$, which were subjectively assessed by respondents.

\section{Results and discussion}

\subsection{Assessment of CSR and its drivers}

$\mathrm{H} 1$ hypothesis (The institutional environment and political relations are the main drivers of CSR level as well as CR of enterprises in selected Balkan countries) was tested by assessing the impact of mean values of the independent variables on dependant variables for selected countries.

$\mathrm{H} 2$ hypothesis (The degree of the impact of the main drivers on CSR in selected Balkan countries is linked to EU accession level) was tested by comparing assessment of average CSR level in scores by respondents in Balkan Countries.

The obtained regression analysis results are shown in Table 2. In addition to coefficients: $b_{0}, b_{1}, b_{2}, b_{3}$, and $b_{4}$, statistical parameters are listed: mean absolute deviation (MAD); mean square error (MSE); mean absolute percent error (MAPE) and standard error of the regression assessment (SE).

Table 2. Corresponding statistical values of parameters for: MON, CRO and SLO (source: calculated by authors)

\begin{tabular}{|c|c|c|c|}
\hline Parameters & Case 1: MON & Case 2: CRO & Case 3: SLO \\
\hline$b_{0}$ & -0.414 & 0.538 & 0.184 \\
\hline$b_{1}$ & 0.395 & 0.820 & 0.232 \\
\hline$b_{2}$ & 0.433 & 0.169 & 0.108 \\
\hline$b_{3}$ & 0.037 & -0.053 & 0.369 \\
\hline$b_{4}$ & 0.117 & -0.027 & 0.266 \\
\hline $\bar{Y}_{s}$ & $\mathbf{2 . 4 3}$ & $\mathbf{2 . 8 9}$ & $\mathbf{3 . 5 2}$ \\
\hline MAD & 0.274 & 0.133 & 0.152 \\
\hline MSE & 0.121 & 0.041 & 0.043 \\
\hline MAPE, $\%$ & 12.57 & 4.54 & 0.046 \\
\hline SE & 0.3067 & 0.2083 & 0.2133 \\
\hline
\end{tabular}


Using information in Table 2, we can discuss the main results:

- Mean absolute deviation provides the data on how much the value of the dependent variable, obtained through multiple regression analysis, is in line to the assessed value by the experts. The obtained values $0.274,0.133 \& 0.152$ respectively show that model quite well reproduces the perception of experts.

- Mean square error provides information on consistency of the model. The obtained numbers $0.121,0.041 \& 0.043$ respectively in the case of analysed samples in MON, CRO and SLO show the satisfactory matching of the model with the real data obtained during the expert's survey.

- Mean absolute percent error also indicates the consistency of model. The obtained numbers (respectively): $12.57 \%, 4.56 \% \& 0.04 \%$ for MON, CRO, and SLO show that the model is consistent.

- Standard error of the regression estimates or standard deviation of regression provides the confidence intervals around the regression line. This estimate shows how much the dependent variable value, estimated in model, can vary numerically. The following values were obtained: in the case of MNO it is 0.30 , for CRO -0.20 , for SLO -0.21 .

Figures 3-5 show the genuine value of the dependent variable $\mathrm{Y}$, assessed on the basis of subjective estimates of 270 experts from MON, CRO and SLO, as well as the estimated value of the dependent variable, calculated in Model $\bar{Y}$.

Based on the analysis of each sample in these 3 different countries, the data given in Table 3 (illustrated with Figure 6) were obtained. The analysis of the linear dependence between the dependent variable and the average values of independent variables shows the following: the variable $\mathrm{Mv}_{4}$ and $\mathrm{Mv}_{2}$ have the greatest influence on the dependent variable in the case of Slovenia. In addition, the smallest influence of independent variable $M v_{1}$ and $M v_{3}$ exists in Montenegro.

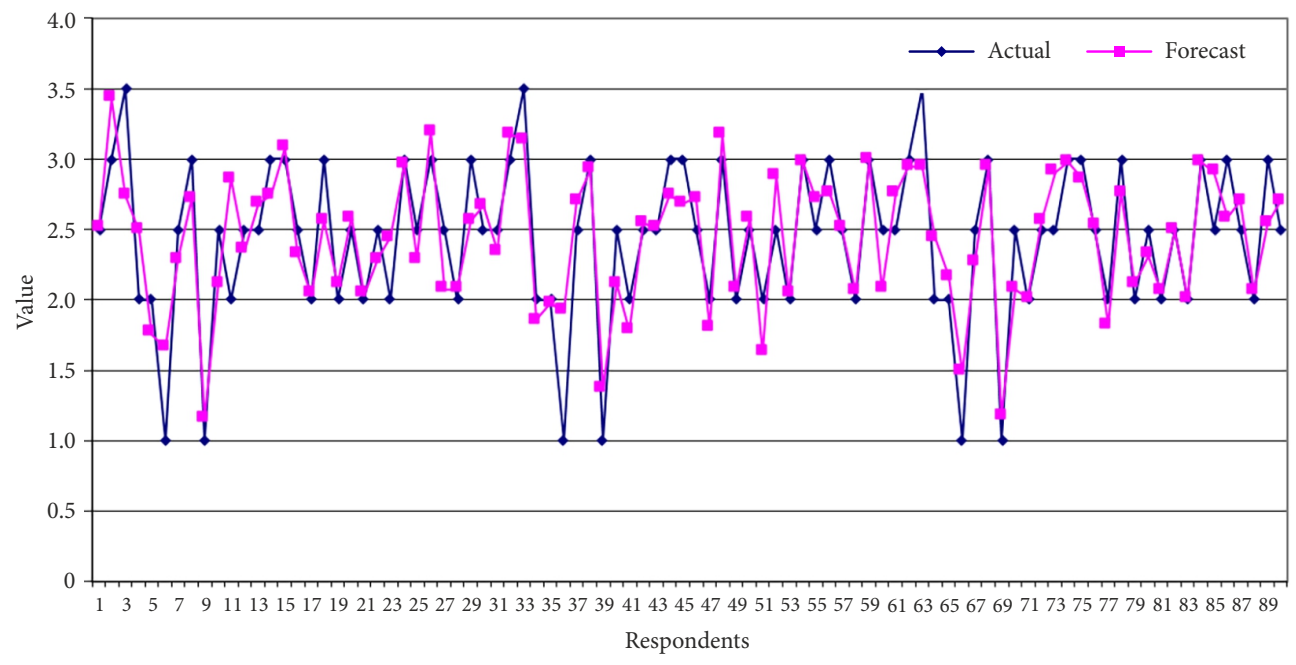

Figure 3. The values of the dependent variables assessed by experts and calculated by Model $\bar{Y}$ for MON (source: calculated by authors) 


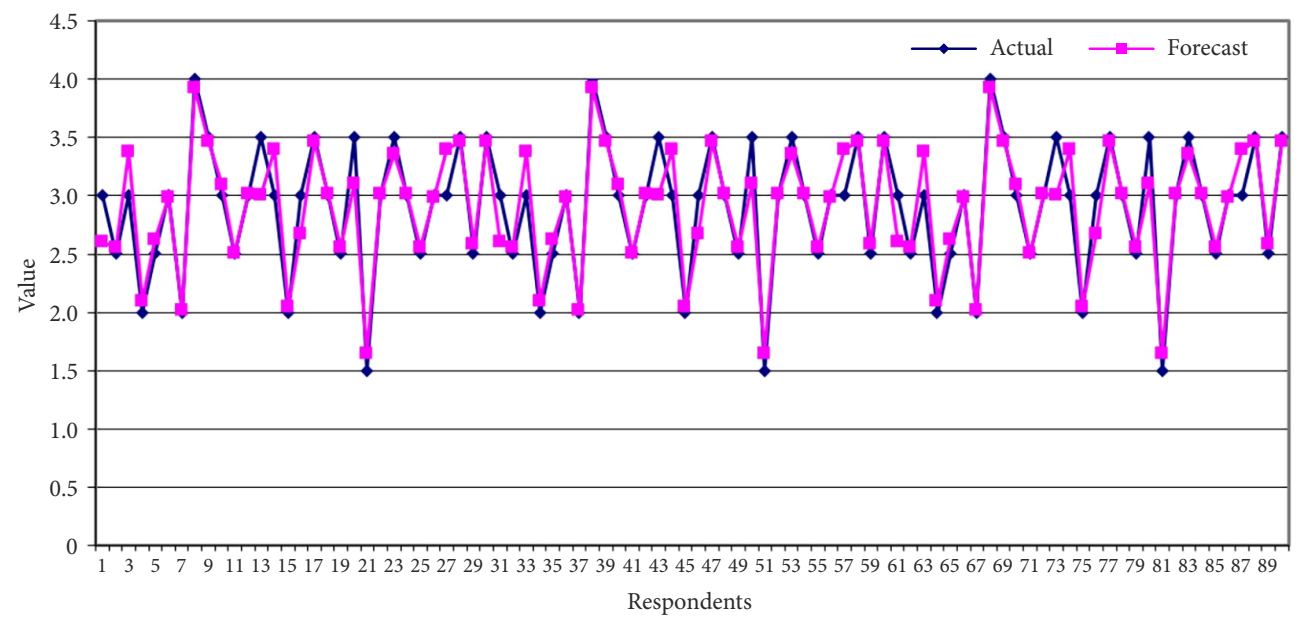

Figure 4 . The values of the dependent variables assessed by experts and calculated by Model $Y$ for CRO (source: calculated by authors)

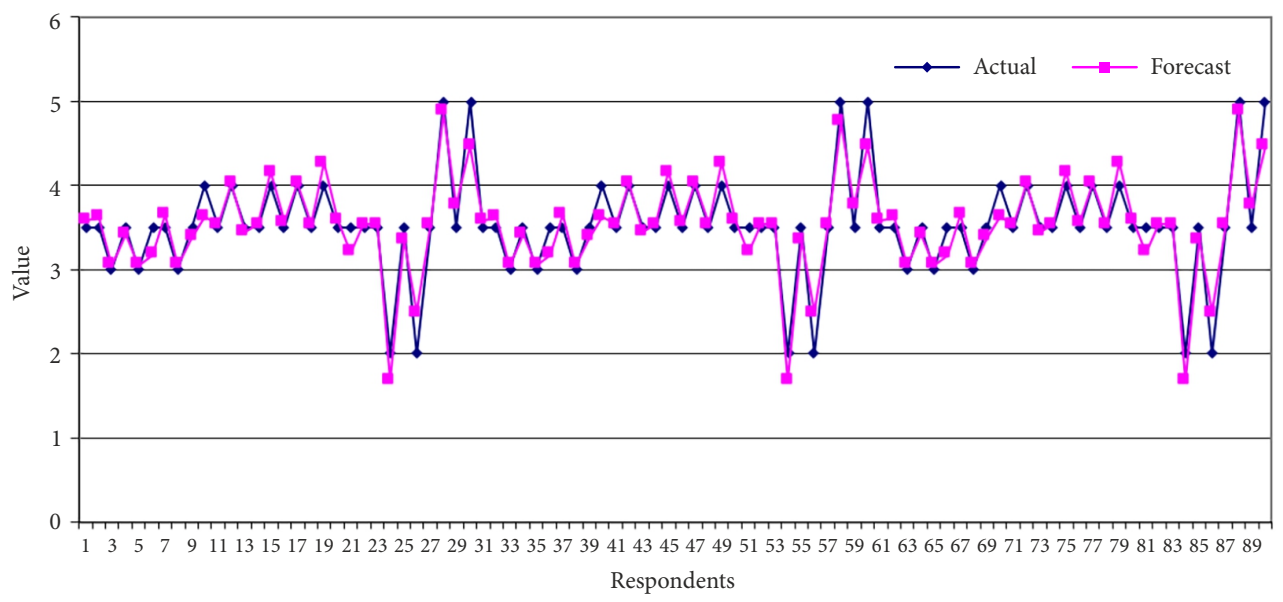

Figure 5 . The values of the dependent variables assessed by experts and calculated by Model $\bar{Y}$ for SLO (source: calculated by authors)

Table 3. Mean values of the independent variables and their impact to the dependant variable (source: calculated by authors)

\begin{tabular}{|c|c|c|c|}
\hline Rank & Case 1: MON & Case 2: CRO & Case 3: SLO \\
\hline 1 & $\mathrm{Mv}_{4}[4.43]$ & $\mathrm{Mv}_{4}[3.95]$ & $\mathrm{Mv}_{2}[4.45]$ \\
\hline 2 & $\mathrm{Mv}_{2}[3.31]$ & $\mathrm{Mv}_{2}[3.78]$ & $\mathrm{Mv}_{4}[3.96]$ \\
\hline 3 & $\mathrm{Mv}_{3}[2.55]$ & $\mathrm{Mv}_{3}[2.86]$ & $\mathrm{Mv}_{1}[3.18]$ \\
\hline 4 & $\mathrm{Mv}_{1}[2.00]$ & $\mathrm{Mv}_{1}[2.86]$ & $\mathrm{Mv}_{3}[3.06]$ \\
\hline
\end{tabular}




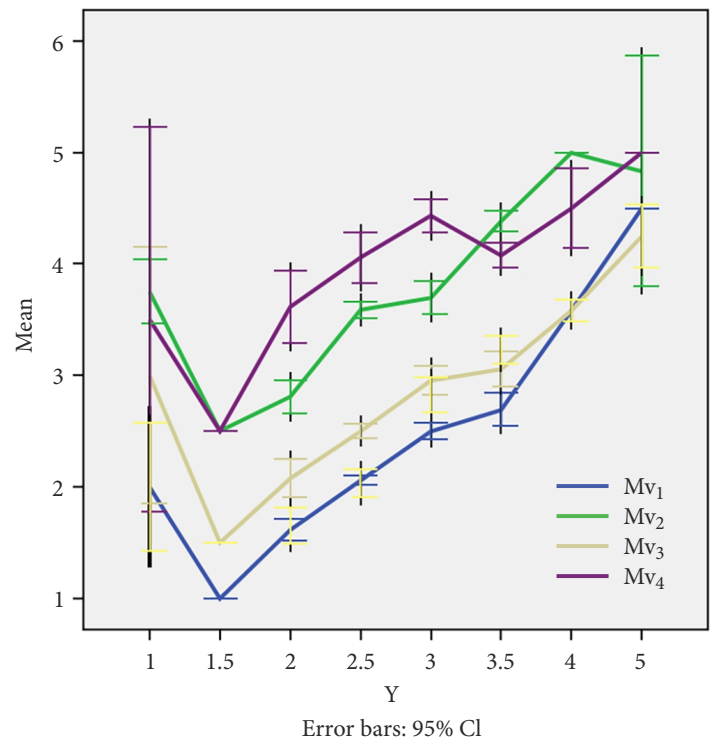

Figure 6. Dependant variable $(\mathrm{Y})$ vs. independent variables $\left(\mathrm{Mv}_{1-4}\right)$

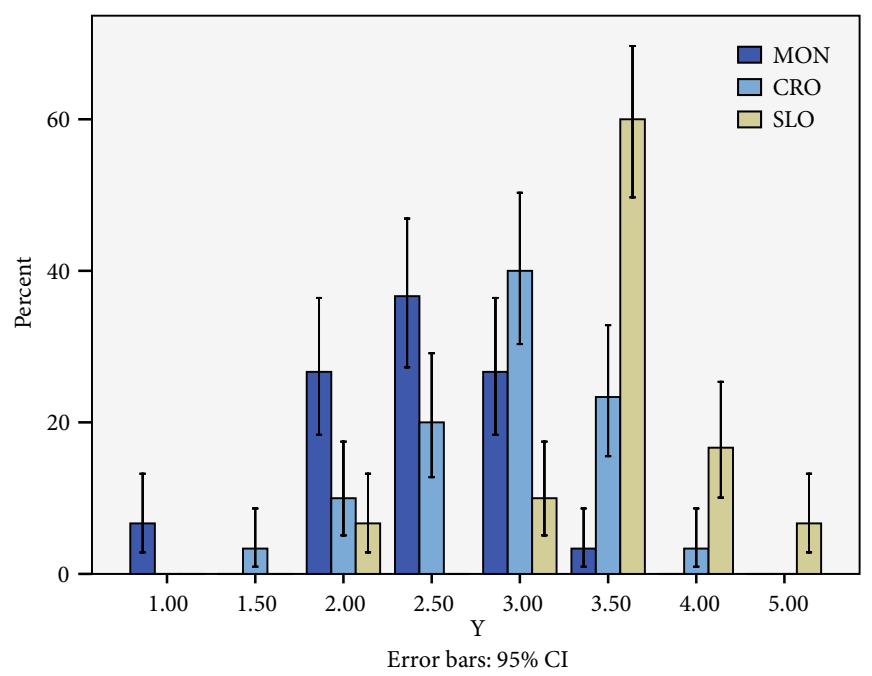

Figure 7. The percentage of estimates from 1 to 5 in the set of dependent variable (Y) (source: calculated by authors)

The average values of the dependant variable estimated by the respondents are shown in Figure 7, and expressed in \%, for each of the analysed categories, i.e., MON, CRO, and SLO. It is obvious that the highest percentage of respondents (over 40\%) from all three countries rated the achieved level of CSR medium (2.5-3.5). The smaller percentages were associated to weak (1-1.5) and also smaller to strong (4-5) level of CSR achieved which exposed to the citizens in accordance to the subjective judgments of the respondents from the analysed countries. This analysis is done throughout the whole sample. 
The correlation coefficient values (R) are above 0.6 not only at level of an individual countries (see Table 1), but also for all countries (Table 4), suggesting strong linear dependence. Coefficient of determination $\left(R^{2}\right)$ indicates that $\bar{Y}$ is determined $70 \%$ by selected independent variables, which means the regression predictions approximate the real data points, and that variation of $\bar{Y}$ is $67 \%$ explained by changes of the selected independent variables.

Table 4. Summary of the model for all countries

\begin{tabular}{|c|c|c|c|}
\hline $\mathrm{R}$ & $\mathrm{R}^{2}$ & Adjusted $\mathrm{R}$ square & Std. error of the estimate \\
\hline $0.913(\mathrm{a})$ & 0.833 & 0.831 & 0.30061 \\
\hline
\end{tabular}

Additionally, the calculation of respondents for each of the categories was performed by analogy with Table 2 . The results of these additional analyses are given in Table 5 . The presented data shows the similarity of answers from far different groups of respondents. The low assessment of university professors and assistants is expected regarding the level of the achieved level of CSR in MON, and CRO. And the rank of assessment the achieved level of CSR relates to the countries pattern.

Table 5. Mean values of the dependent variable $\bar{Y}_{s}$ in the case of MON, CRO, SLO different categories of respondents (source: calculated by authors)

\begin{tabular}{|c|c|c|c|c|c|c|c|c|c|c|c|c|}
\hline \multicolumn{13}{|c|}{ Owners of companies in the private sector } \\
\hline & \multicolumn{4}{|c|}{ MON } & \multicolumn{4}{|c|}{$\mathrm{CRO}$} & \multicolumn{4}{|c|}{ SLO } \\
\hline & $\mathrm{Mv}_{1}$ & $\mathrm{Mv}_{2}$ & $\mathrm{Mv}_{3}$ & $\mathrm{Mv}_{4}$ & $\mathrm{Mv}_{1}$ & $\mathrm{Mv}_{2}$ & $\mathrm{Mv}_{3}$ & $\mathrm{Mv}_{4}$ & $\mathrm{Mv}_{1}$ & $\mathrm{Mv}_{2}$ & $\mathrm{Mv}_{3}$ & $\mathrm{Mv}_{4}$ \\
\hline & 1.93 & 3.38 & 2.25 & 4.2 & 2.45 & 3.85 & 3.05 & 4 & 2.95 & 4.2 & 2.8 & 4 \\
\hline$b_{0}$ & \multicolumn{4}{|c|}{-1.25} & \multicolumn{4}{|c|}{-0.85} & \multicolumn{4}{|c|}{0.976} \\
\hline$b_{1}$ & \multicolumn{4}{|c|}{0.27} & \multicolumn{4}{|c|}{0.05} & \multicolumn{4}{|c|}{0.623} \\
\hline$b_{2}$ & \multicolumn{4}{|c|}{0.76} & \multicolumn{4}{|c|}{0.80} & \multicolumn{4}{|c|}{-0.090} \\
\hline$b_{3}$ & \multicolumn{4}{|c|}{0,21} & \multicolumn{4}{|c|}{0.07} & \multicolumn{4}{|c|}{-0.071} \\
\hline$b_{4}$ & \multicolumn{4}{|c|}{0.01} & \multicolumn{4}{|c|}{0.03} & \multicolumn{4}{|c|}{0.328} \\
\hline $\bar{Y}_{s}$ & \multicolumn{4}{|c|}{2.40} & \multicolumn{4}{|c|}{2.9} & \multicolumn{4}{|c|}{3.55} \\
\hline MAD & \multicolumn{4}{|c|}{0.238} & \multicolumn{4}{|c|}{0.164} & \multicolumn{4}{|c|}{0.122} \\
\hline MSE & \multicolumn{4}{|c|}{0.092} & \multicolumn{4}{|c|}{0.029} & \multicolumn{4}{|c|}{0.018} \\
\hline MAPE & \multicolumn{4}{|c|}{10.19} & \multicolumn{4}{|c|}{5.78} & \multicolumn{4}{|c|}{0.036} \\
\hline SE & & & 699 & & & & 112 & & & & 850 & \\
\hline & & & State & Iminis & ation & ficials & ith ar & caden & title & & & \\
\hline & & & & & & & & & & & & \\
\hline & $\mathrm{Mv}_{1}$ & $\mathrm{Mv}_{2}$ & $\mathrm{Mv}_{3}$ & $\mathrm{Mv}_{4}$ & $\mathrm{Mv}_{1}$ & $\mathrm{Mv}_{2}$ & $\mathrm{Mv}_{3}$ & $\mathrm{Mv}_{4}$ & $\mathrm{Mv}_{1}$ & $\mathrm{Mv}_{2}$ & $\mathrm{Mv}_{3}$ & $\mathrm{Mv}_{4}$ \\
\hline & 2.0 & 3.4 & 2.3 & 4.7 & 2.58 & 3.98 & 2.88 & 4.08 & 2.9 & 4.41 & 3.06 & 3.96 \\
\hline$b_{0}$ & & & & & & & & & & & & \\
\hline$b_{1}$ & & & & & & & & & & & & \\
\hline$b_{2}$ & & & & & & & & & & & & \\
\hline$b_{3}$ & & & & & & & & & & & & \\
\hline$b_{4}$ & & & & & & & & & & & & \\
\hline
\end{tabular}


End of Table 5

\begin{tabular}{|c|c|c|c|c|c|c|c|c|c|c|c|c|}
\hline $\bar{Y}_{s}$ & \multicolumn{4}{|c|}{2.43} & \multicolumn{4}{|c|}{3.09} & \multicolumn{4}{|c|}{3.53} \\
\hline MAD & \multicolumn{4}{|c|}{0.138} & \multicolumn{4}{|c|}{0.107} & \multicolumn{4}{|c|}{0.155} \\
\hline MSE & \multicolumn{4}{|c|}{0.027} & \multicolumn{4}{|c|}{0.027} & \multicolumn{4}{|c|}{0.044} \\
\hline MAPE & \multicolumn{4}{|c|}{5.77} & \multicolumn{4}{|c|}{3.50} & \multicolumn{4}{|c|}{4.72} \\
\hline SE & \multicolumn{4}{|c|}{0.18533} & \multicolumn{4}{|c|}{0.17972} & \multicolumn{4}{|c|}{0.22907} \\
\hline \multicolumn{13}{|c|}{ University professors and assistants } \\
\hline & \multicolumn{4}{|c|}{ MON } & \multicolumn{4}{|c|}{$\mathrm{CRO}$} & \multicolumn{4}{|c|}{ SLO } \\
\hline & $\mathrm{Mv}_{1}$ & $\mathrm{Mv}_{2}$ & $\mathrm{Mv}_{3}$ & $\mathrm{Mv}_{4}$ & $\mathrm{Mv}_{1}$ & $\mathrm{Mv}_{2}$ & $\mathrm{Mv}_{3}$ & $\mathrm{Mv}_{4}$ & $\mathrm{Mv}_{1}$ & $\mathrm{Mv}_{2}$ & $\mathrm{Mv}_{3}$ & $\mathrm{Mv}_{4}$ \\
\hline & 1.9 & 3.3 & 2.6 & 4.4 & 2.2 & 3.5 & 2.7 & 3.9 & 2.9 & 4.6 & 3.4 & 4.1 \\
\hline$b_{0}$ & \multicolumn{4}{|c|}{-1.55} & \multicolumn{4}{|c|}{0.40} & \multicolumn{4}{|c|}{-0.18} \\
\hline$b_{1}$ & \multicolumn{4}{|c|}{0.11} & \multicolumn{4}{|c|}{0.97} & \multicolumn{4}{|c|}{0.22} \\
\hline$b_{2}$ & \multicolumn{4}{|c|}{0.06} & \multicolumn{4}{|c|}{0.11} & \multicolumn{4}{|c|}{0.19} \\
\hline$b_{3}$ & \multicolumn{4}{|c|}{0.02} & \multicolumn{4}{|c|}{0.07} & \multicolumn{4}{|c|}{0.45} \\
\hline$b_{4}$ & \multicolumn{4}{|c|}{0.77} & \multicolumn{4}{|c|}{-0.09} & & & & \\
\hline $\bar{Y}_{s}$ & & & & & & & & & & & & \\
\hline MAD & & & & & & & & & & & & \\
\hline MSE & & & & & & & & & & & & \\
\hline MAPE & & & & & & & & & & & & \\
\hline SE & & & & & & & & & & & 53 & \\
\hline
\end{tabular}

\subsection{The impact of corporate social responsibility on corporate reputation}

Today, CR tends to be one of the most important aspects of a growing business. Our research in the observed countries include respondents' assessment of the level of CR. Regarding $\mathrm{CR}$, our starting hypothesis is that correlation between the level of CSR and CR is higher in the countries having greater level of CSR. Through analysis of the collected data, first of all correlation analysis, we verify the starting hypothesis. The results are shown in Table 6, and Figures 8, 9, and 10 .

As one can see from Table 6 and Figures 9-10 correlation between the level of CSR and CR is the highest in Slovenia with a greater level of CSR among other selected Balkan countries.

Table 6. Correlation between CSR and CR

\begin{tabular}{|c|c|c|c|}
\hline Parameters & Case 1: MON & Case 2: CRO & Case 3: SLO \\
\hline CSR & 2.43 & 2.89 & 3.52 \\
\hline CR & 1.96 & 2.86 & 3.18 \\
\hline $\mathrm{r}$ & 0.455 & 0.627 & 0.820 \\
\hline
\end{tabular}




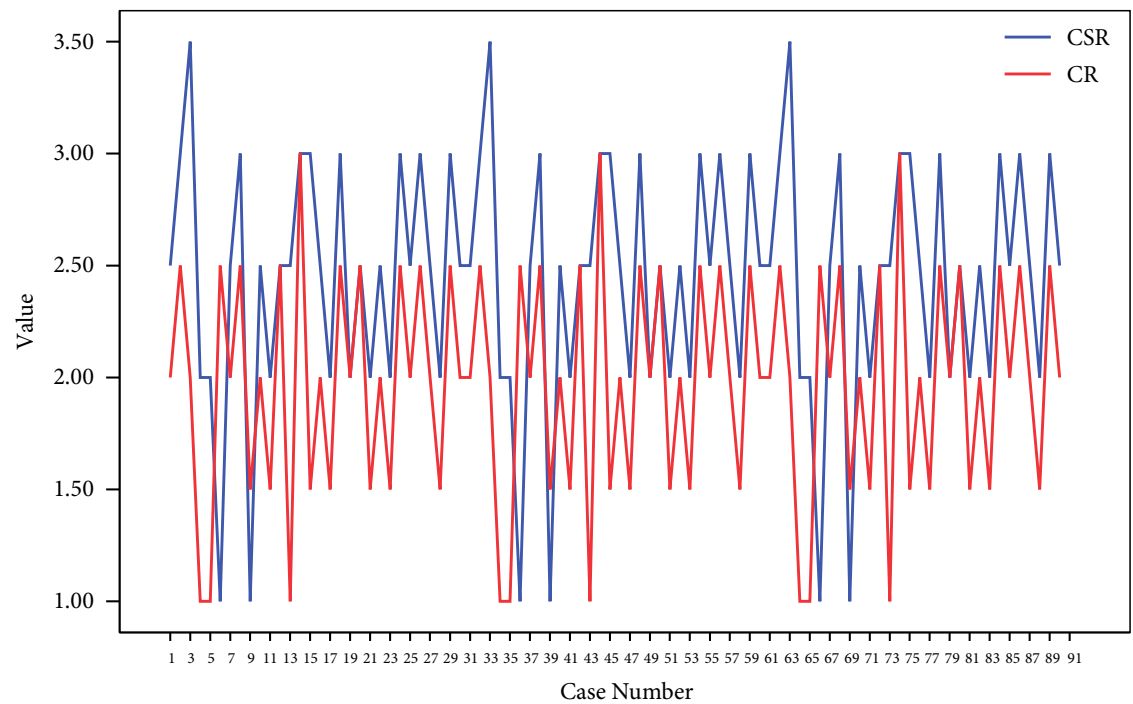

Figure 8. CSR - CR relation in Case MON (source: own calculations)

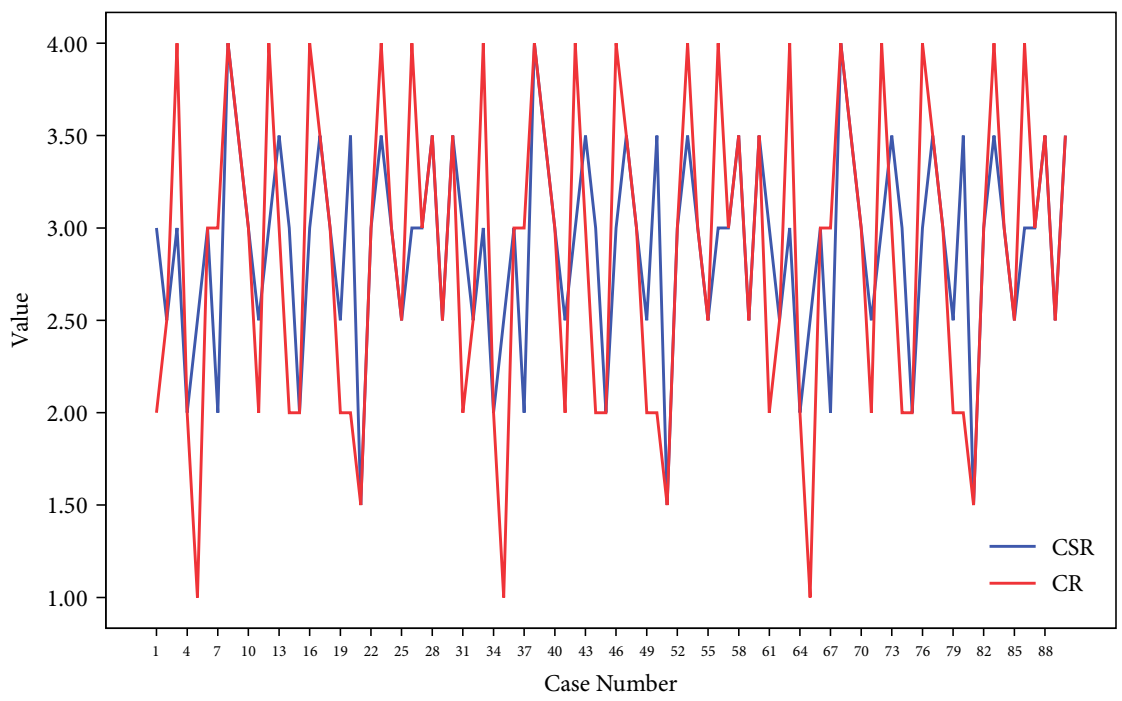

Figure 9. CSR - CR relation in Case CRO

\section{Conclusions}

Based on the conducted literature review, it was found that the prevailing influencing factors on achieved CRS level are as follows: the political relations, institutional environment, executive characteristics, customers' expectations.

Therefore, the functional dependencies between the dependent variable - the level of CSR, and the independent variables (political relations, institutional environment, executive characteristics and customers' expectations) were established. 


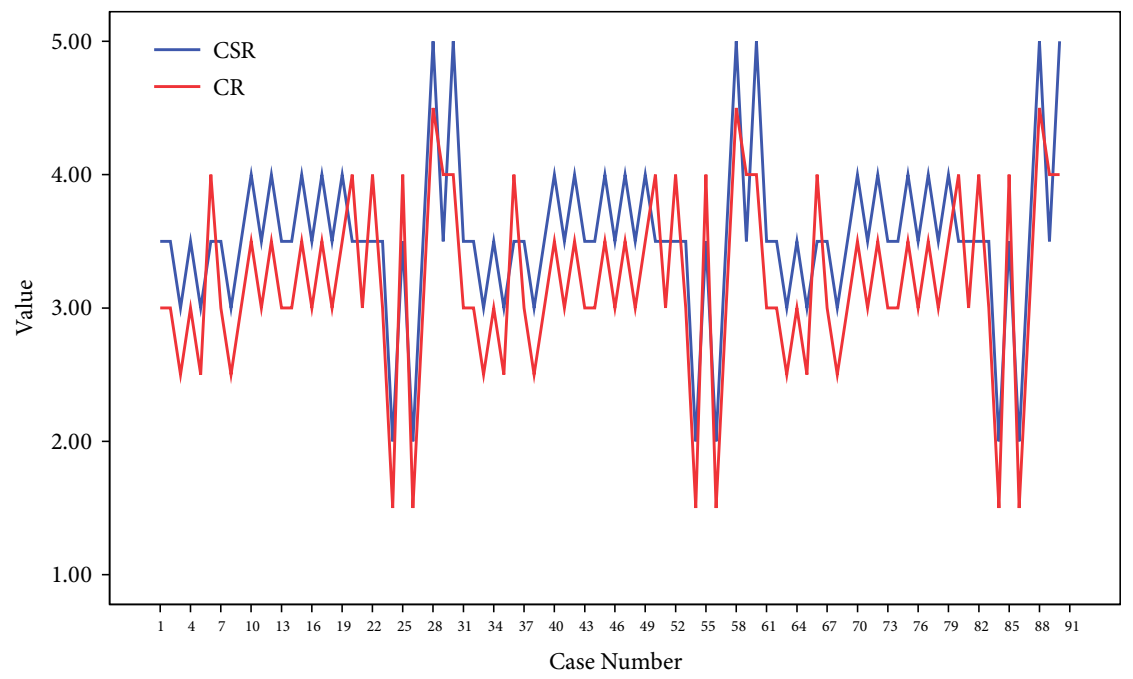

Figure 10. CSR - CR relation in Case SLO

On the basis of statistical modelling it has been shown that the mean expected values of the dependent variable are: 2.43 (MON), 2.89 (CRO), and 3.52 (SLO). Also, the rank of independent variables influence on the dependant variable was established. Testing impact of CSR to CR showed that countries with the higher level of CSR, have achieved the greater level of CR. According to those stated above, the starting hypothesis in the study has been fully verified.

The Slovenia (joined EU in 2004) has the highest CSR level, then followed by Croatia (accessed to EU in 2013) and Montenegro (not EU member state). The political factor has the highest impact on CSR level in all investigated countries, institutional environment is the next; Correlation between the level of CSR and CR is higher in the countries having greater level of CSR;

From the perspective of enhancing the level of CSR, the findings of this study give references for deciding on the directions, that when setting up a good strategy of the development, the given factors and their influence should be considered as the most important. These factors are, on the basis of regression analysis, significant elements in the influence to the level of CSR. The selected independent variables in the model explained $67 \%$ of the variation of the level of CSR.

Despite some limitations linked to developed model, this study provides the notable contributions. First, it fills up deficit of research in this field. Second, the analysis of the impact factors is given, with certain extensions compared to the previous studies. Third, the theoretical framework for the research of the achieved level of CSR can be generalized. The developed model and questionnaires can be applied in other countries for assessment of CSR level and its main drivers where other data on assessment of CSR initiatives is not available.

Further research should be carried out in the direction of the possible inclusion of additional independent variables, or the establishment of different, more complex aspects of 
functional dependence among the variables. There are significant internal reserves for the improvement of all independent factors in order to achieve the highest level of CSR in observed countries.

The structural equation modelling can be applied in future research to overcome limitation of the conducted study in order to define the mediating and moderating role of specific factors having impact on CSR and CR and their relationships.

The state policies to promote CSR in former Yugoslavia countries are necessary. If the observed countries strive to develop CSR and create a competitive advantage for their companies in term of increased reputation, understanding the importance of selected factors in this model provides for development of effective policies to promote CSR as the political and institutional environment is the main driver of CSR development.

\section{Funding}

This work was supported by the Program for the Innovative Talents of Higher Education Institutions of Shanxi (PTIT) under Grant (20191043); the Planning Program for Philosophy and Social Sciences of Shanxi under Grant (No. W20191020); Key R\&D Program of Shanxi Province, China (Social Development) under Grant (201903D321004); Taiyuan University of Science \& Technology Scientific Research Initial Funding (TYUST SRIF) under Grants (No. W20182014 and No. W20192003).

\section{References}

Abbas, M., Gao, Y., \& Shah, S. S. H. (2018). CSR and customer outcomes: The mediating role of customer engagement. Sustainability, 10(11), 4243. https://doi.org/10.3390/su10114243

Aguilera, R. V., Rupp, D. E., Williams, C. A., \& Gajnapathi, J. (2007). Putting the S back in corporate social responsibility: A multilevel theory of social change in organizations. Academy of Management Review, 32(3), 836-863. https://doi.org/10.5465/amr.2007.25275678

Aguilera, R. V., \& Jackson, G. (2003). The cross-national diversity of corporate governance: Dimensions and determinants. Academy of Management Review, 28(3), 447-465.

https://doi.org/10.5465/amr.2003.10196772

Ali, W., Frynas, J. G., \& Mahmood, Z. (2017). Determinants of Corporate Social Responsibility (CSR) disclosure in developed and developing countries: A literature review. Corporate Social Responsibility and Environmental Management, 24(4), 273-294. https://doi.org/10.1002/csr.1410

Aoki, M. (2001). Information, corporate governance and institutional diversity: Competitiveness in Japan, the USA and transitional economies. Oxford University Press.

Apreda, R. (2006). The semantics of governance: The common thread running through corporate, public, and global governance. Corporate Ownership and Control, 3(2), 45-53. https://doi.org/10.22495/cocv3i2p6

Babić, V. (2010). Corporate governance in transition economies. Theme, 34(2), 555-568.

Bakan, J. (2004). The corporation: The pathological pursuit of profit and power. Free Press.

Balakrishnan, N., Render, B., \& Stair, R. M. (2012). Managerial decision modelling with spreadsheets ( $3^{\text {th }}$ ed.). Pearson.

Barker, V. L. III, \& Mueller, G. C. (2002). CEO characteristics and firm R\&D spending. Management Science, 48(6), 711-820. https://doi.org/10.1287/mnsc.48.6.782.187 
Bertsekas, D. P., \& Nedic, A. (2003). Least squares policy evaluation algorithms with linear function approximation. Discrete Event Dynamic Systems, 13(1-2), 79-110. https://doi.org/10.1023/A:1022192903948

Bice, S. (2015). Corporate social responsibility as institution: A social mechanisms framework. Journal of Business Ethics, 143(1), 1-18. https://doi.org/10.1007/s10551-015-2791-1

Carroll, A. B. (1979). A Three-dimensional conceptual model of corporate social performance. Academy of Management Review, 4(4), 497-505. https://doi.org/10.5465/amr.1979.4498296

Carroll, A. B. (1999). Corporate social responsibility: Evolution of a definitional construct. Business and Society, 38(3), 268-295. https://doi.org/10.1177/000765039903800303

Carroll, A. B. (2000). Ethical challenges for business in the new millennium: Corporate social responsibility and models of management morality. Business Ethics Quarterly, 10(1), 33-42. https://doi.org/10.2307/3857692

Carroll, A. B. (2016). Carroll's pyramid of CSR: Taking another look. International Journal of Corporate Social Responsibility, 1(1), 1-8. https://doi.org/10.1186/s40991-016-0004-6

Carroll, A. B., \& Bucholtz, A. K. (2008). Business and society: Ethics and stakeholder management ( $7^{\text {th }}$ ed.). USA: Cengage Learning.

Cavalic, A. (2017). The pyramid of corporate social responsibility in the companies of Bosnia and Herzegovina. In The Proceedings of $5^{\text {th }}$ International Scientific Conference on Economy of Integration (ICEI) (pp. 671-681). Tuzla, Bosnia \& Herzegovina.

Chen, J., Huang, J., Zheng, L., \& Zhang, Ch. (2019). An empirical analysis of telecommunication infrastructure promoting the scale of international service trade: Based on the panel data of countries along the belt and road. Transformations in Business \& Economics, 18(2), 124-139.

Chin, M. K., Hambrick, D. C., \& Treviño, L. K. (2013). Political ideologies of CEOs: The influence of executives' values on corporate social responsibility. Administrative Science Quarterly, 58(2), 197-232. https://doi.org/10.1177/0001839213486984

Christensen, L. J., Mackey, A., \& Whetten, D. (2013). Taking responsibility for corporate social responsibility: The role of leaders in creating, implementing, sustaining, or avoiding socially responsible firm behaviours. Academy of Management Perspectives, 28(2), 164-178. https://doi.org/10.5465/amp.2012.0047

Crane, A., Mcwilliams, A., Matten, D., Siegel, D. S., \& Moon, J. (2009). The corporate social responsibility agenda. In A. Crane, D. Matten, A. McWilliams, J. Moon, \& D. S. Siegel (Eds.), The Oxford handbook of corporate social responsibility. Oxford University Press. https://doi.org/10.1093/oxfordhb/9780199211593.001.0001

Danubianu, M., \& Teodorescu, C. (2017). Impact of corporate social responsibility on sustainable enterprise development. Journal of Contemporary Issues in Economics and Business, 11(1), 129-139. https://doi.org/10.1515/pesd-2017-0012

Dean, D. H. (2002). Associating the corporation with a charitable event through sponsorship: Measuring the effects on corporate-community relations. Journal of Advertising, 31(4), 77-87. https://doi.org/10.1080/00913367.2002.10673687

Dialogue of Civilizations Research Institute. (2018). The rise and fall of market socialism in Yugoslavia (special report). Berlin, Germany.

Dixit, A. (2009). Governance institutions and economic activity. American Economic Review, 99(1), 5-24. https://doi.org/10.1257/aer.99.1.5

Draskovic, M., \& Stjepcevic, J. (2012). Institutional framework of corporate governance with reference to the former Yugoslav transition economies. Montenegrin Journal of Economics, 8(4), 27-41.

Draskovic, V., \& Lojpur, A. (2013). The importance of the institutional framework in regulating corporate social responsibility. Montenegrin Journal of Economics, 9(2), 39-46.

Dummett, K. (2006). Drivers for Corporate Environmental Responsibility (CER). Environment, Development and Sustainability, 8(3), 375-389. https://doi.org/10.1007/s10668-005-7900-3 
Dyduch, J., \& Krasodomska, J. (2017). Determinants of corporate social responsibility disclosure: An empirical study of Polish listed companies. Sustainability, 9(11), 1934. https://doi.org/10.3390/su9111934

Everard, M., Reed, M. S., \& Kenter, J. O. (2016) The ripple effect: institutionalising pro-environmental values to shift societal norms and behaviours. Ecosystem Services, 21(Part B), 230-240. https://doi.org/10.1016/j.ecoser.2016.08.001

Fiss, P. C. (2008). Institutions and corporate governance. In The SAGE Handbook of Organizational Institutionalism (Chaper 15). https://sk.sagepub.com/reference/hdbk_orginstitution/n16.xml

Fox, T., Ward, H., \& Howard, B. (2002). Public sector roles in strengthening corporate social responsibility: A baseline study. https://pubs.iied.org/16017IIED

Garriga, E., \& Melé, D. (2004). Corporate social responsibility theories: Mapping the territory. Journal of Business Ethics, 53(1-2), 51-71. https://doi.org/10.1023/B:BUSI.0000039399.90587.34

Hafenbradl, S., \& Waeger, D. (2016). Ideology and the microfoundations of CSR: Why executives believe in the business case for CSR and how this affects their CSR engagements. Academy of Management Journal, 60(4), 1582-1606. https://doi.org/10.5465/amj.2014.0691

Higgins, K. T. (2002). Marketing with a conscience. Marketing Management, 11(4), 12-15.

Hillenbrand, C., \& Money, K. (2007). Corporate responsibility and corporate reputation: Two separate concepts or two sides of the same coin? Corporate Reputation Review, 10(4), 261-277. https://doi.org/10.1057/palgrave.crr.1550057

Huang, H., \& Zhao, Zh. (2016). The influence of political connection on corporate social responsibility - evidence from Listed private companies in China. International Journal of Corporate Social Responsibility, 1(1), 1-19. https://doi.org/10.1186/s40991-016-0007-3

Hult, G. T. M. (2011). Market-focused sustainability: Market orientation plus! Journal of the Academy of Marketing Science, 39(1), 1-6. https://doi.org/10.1007/s11747-010-0223-4

Iamandi, I.-E., \& Constantin, L.-G. (2012). Quantifying corporate social responsibility involvement in art and culture projects in Romania and Bulgaria. Procedia Economics and Finance, 3, 1122-1127. https://doi.org/10.1016/S2212-5671(12)00284-5

Ioannou, I., \& Serafeim, G. (2012). What drives corporate social performance? The role of nation-level institutions. Journal of International Business Studies, 43(9), 834-864.

https://doi.org/10.1057/jibs.2012.26

Jonker, J. (2005). CSR wonderland: Navigating between movement, community and organization. Journal of Corporate Citizenship, 2005(20), 19-20. https://doi.org/10.9774/GLEAF.4700.2005.wi.00004

Kang, C., Germann, F., \& Grewal, R. (2016). Washing away your sins? Corporate social responsibility, corporate social irresponsibility, and firm performance. Journal of Marketing, 80(2), 59-79. https://doi.org/10.1509/jm.15.0324

Koleva, P., Rodet-Kroichvili, N., David, P., \& Marasova, J. (2010). Is corporate social responsibility the privilege of developed market economies? Some evidence from Central and Eastern Europe. International Journal of Human Resource Management, 21(2), 274-293. https://doi.org/10.1080/09585190903509597

Kolk, A. (2016). The social responsibility of international business: From ethics and the environment to CSR and sustainable development. Journal of World Business, 51(1), 23-34. https://doi.org/10.1016/j.jwb.2015.08.010

Kudłak, R., Szöcs, I., Krumay, B., \& Martinuzzi, A. (2018). The future of CSR-Selected findings from a Europe-wide Delphi study. Journal of Cleaner Production, 183, 282-291. https://doi.org/10.1016/j.jclepro.2018.02.119

Lewis, S. (2003). Reputation and corporate responsibility. Journal of Communication Management, 7(4), 356-366. https://doi.org/10.1108/13632540310807494

Li, J., Sun, X., \& Li, G. (2018). Relationships among green brand, brand equity and firm performance: Empirical evidence from China. Transformations in Business and Economics, 17(3), 221-236. 
Li, J., Zhang, F., \& Sun, S. (2019). Building consumer-oriented CSR differentiation strategy. Sustainability, 11(3), 664. https://doi.org/10.3390/su11030664

Lu, J., Ren, L., He, Y., Lin, W. \& Streimikis, J. (2019a). Linking corporate social responsibility with reputation and brand of the firm. Amfiteatru Economic, 21(51), 442-460. https://doi.org/10.24818/EA/2019/51/422

Lu, J., Ren, L., Lin, W., He, Y., \& Streimikis, J. (2019b). Policies to promote Corporate social responsibility (CSR) and assessment of CSR impacts. E+M. Ekonomie a Management, 22(1), 82-98. https://doi.org/10.15240/tul/001/2019-1-006

Lu, J., Ren, L., Qiao, J., Lin, W., \& He, Y. (2019c). Female executives and corporate social responsibility performance: A dual perspective of differences in institutional environment and heterogeneity of foreign experience. Transformations in Business \& Economics, 18(2), 174-196.

Maak, T., Pless, N. M., \& Voegtlin, C. (2016). Business statesman or shareholder advocate? CEO responsible leadership styles and the micro-foundations of political CSR. Journal of Management Studies, 53(3), 463-493. https://doi.org/10.1111/joms.12195

Maitland, E., Nicholas, S., \& Boyce, G. (2009). The economics of governance: Transaction cost economics and new institutional economics. http://citeseerx.ist.psu.edu/viewdoc/summary?doi=10.1.1.511.4859

Mapelli, F., Arena, M., \& Azzone, G. (2016). What drivers determine CSR strategies in the energy industry? Evidence from Italy. In The European Conference on Sustainability, Energy \& the Environment 2016 Official Conference Proceedings. The International Academic Forum (IAFOR).

Margolis, J. D., \& Walsh, J. P. (2003). Misery loves companies: Rethinking social initiatives by business. Administrative Science Quarterly, 48(2), 268-289. https://doi.org/10.2307/3556659

Martin, L. (2015) Incorporating values into sustainability decision-making. Journal of Cleaner Production, 105, 146-156. https://doi.org/10.1016/j.jclepro.2015.04.014

Matev, D., \& Assenova, M. (2012). Application of corporate social responsibility approach in Bulgaria to support sustainable tourism development. Clean Technologies and Environmental Policy, 14(6), 1065-1073. https://doi.org/10.1007/s10098-012-0519-9

Matten, D., Crane, A., \& Chapple, W. (2003). Behind the mask: Revealing the true face of corporate citizenship. Journal of Business Ethics, 45(1), 109-120. https://doi.org/10.1023/A:1024128730308

Miras-Rodriguez del Mar, M., Martinez-Martinez, D., \& Escobar-Perez, B. (2019). Which corporate governance mechanisms drive CSR disclosure practices in emerging countries? Sustainability, 11(1), 61. https://doi.org/10.3390/su11010061

Moir, L. (2001). What do we mean by corporate social responsibility? Corporate Governance, 1(2), 16-22. https://doi.org/10.1108/EUM0000000005486

Nazari, K., Parvizi, M., \& Emami, M. (2012). Corporate social responsibility: Approaches and perspectives. Interdisciplinary Journal of Contemporary Research in Business, 3(9), 554-563.

North, D. C. (1990). References. In Institutions, institutional change and economic performance (pp. 141-146). Cambridge University Press. https://doi.org/10.1017/CBO9780511808678.017

Öberseder, M., Schlegelmilch, B. B., \& Murphy, P. E. (2013). CSR practices and consumer perceptions. Journal of Business Research, 66(10), 1839-1851. https://doi.org/10.1016/j.jbusres.2013.02.005

Öberseder, M., Schlegelmilch, B. B., Murphy, P. E., \& Gruber, V. (2014). Consumers' perceptions of corporate social responsibility: Scale development and validation. Journal of Business Ethics, 124(1), 101-115. https://doi.org/10.1007/s10551-013-1787-y

Pedersen, E. R. (2006). Between hopes and realities: Reflections on the promises and practices of Corporate Social Responsibility (CSR). Samfundslitteratur.

Pedersen, E. R., \& Neergaard, P. (2006). The bottom line of CSR: A different view. In F. Hond, F. G. A. De Bakker, \& P. Neergaard (Eds.), Managing corporate social responsibility in action: Talking, doing and measuring (pp. 77-91). Ashgate. 
Pesmatzoglou, D., Nikolaou, I. E., Evangelinos, K. I., \& Allan, S. (2014). Extractive multinationals and corporate social responsibility: A commitment towards achieving the goals of sustainable development or only a management strategy? Journal of International Development, 26(2), 187-206. https://doi.org/10.1002/jid.2871

Petrenko, O. V., Aime, F., Ridge, J., \& Hill, A. (2016). Corporate social responsibility or CEO narcissism? CSR motivations and organizational performance. Strategic Management Journal, 37(2), 262-279. https://doi.org/10.1002/smj.2348

Poksinska, B., Dahlgaard, J. J., \& Eklund, J. A. E. (2003). Implementing ISO 14000 in Sweden: Motives, benefits and comparisons with ISO 9000. International Journal of Quality and Reliability Management, 20(5), 585-606. https://doi.org/10.1108/02656710310476543

Postma, T., \& Hermes, N. (2003). Institutions, corporate governance and corporate governance institutions: The case of Estonia. Journal for East European Management Studies, 8(3), 263-292. https://doi.org/10.5771/0949-6181-2003-3-263

Prutina, Z. (2016). The effect of corporate social responsibility on organizational commitment. Management - Journal of Contemporary Management Issues, 21(SI), 227-248.

Prutina, Z., \& Sehic, D. (2016). Employees' perceptions of corporate social responsibility: A case study of award recipient. Ekonomska Misao i Praksa-Economic Thought and Practice, 25(1), 239-259.

Roe, M. J. (2004). The institutions of corporate governance. Harvard John M. Olin Center for Law, Economics, and Business. https://doi.org/10.2139/ssrn.612362

Romani, S., Grappi, S., \& Bagozzi, R. P. (2016). Corporate socially responsible initiatives and their effects on consumption of green products. Journal of Business Ethics, 135(2), 253-264. https://doi.org/10.1007/s10551-015-2541-4

Stanisavljević, M. (2017). Does customer loyalty depend on corporate social responsibility. Journal of Contemporary Issues in Economics and Business, 63(1), 38-46. https://doi.org/10.1515/ngoe-2017-0004

Van Marrewijk, M. (2003). Concepts and definitions of CSR and corporate sustainability: Between agency and communion. Journal of Business Ethics, 44(2-3), 95-105. https://doi.org/10.1007/978-94-007-4126-3_32

Vlachos, P. A., Tsamakos, A., Vrechopoulos, A. P., \& Avramidis, P. K. (2009). Corporate social responsibility: Attributions, loyalty, and the mediating role of trust. Journal of the Academy of Marketing Science, 37(2), 170-180. https://doi.org/10.1007/s11747-008-0117-x

Wood, D. J. (1991). Corporate social performance revisited. Academy of Management Review, 16(4), 691-718. https://doi.org/10.5465/amr.1991.4279616

World Economic Forum. (2019). The global competitiveness report 2019. Geneva, Switzerland.

Yoo, D., \& Lee, J. (2018). The effects of Corporate Social Responsibility (CSR) fit and CSR consistency on company evaluation: The role of CSR support. Sustainability, 10(8), 2956. https://doi.org/10.3390/su10082956

Yoon, Y., Gürhan-Canli, Z., \& Schwarz, N. (2006). The effect of corporate social responsibility (CSR) activities on companies with bad reputations. Journal of Consumer Psychology, 16(4), 377-390. https://doi.org/10.1207/s15327663jcp1604_9

Yuen, K. F., Thai, V. V., \& Wong, Y. D. (2016). Are customers willing to pay for corporate social responsibility? A study of individual-specific mediators. Total Quality Management and Business Excellence, 27(7-8), 912-926. https://doi.org/10.1080/14783363.2016.1187992

Zingales, L. (1997). Corporate governance. https://cepr.org/active/publications/discussion_papers/ dp.php?dpno=1806

Zink, K. J. (2007). Stakeholder orientation and corporate social responsibility as a precondition for sustainability. Total Quality Management \& Business Excellence, 16(8-9), 1041-1052.

https://doi.org/10.1080/14783360500163243 